\title{
The effects of ductal size on the severity of pulmonary hypertension in children with patent ductus arteriosus (PDA): a multi-center study
}

\author{
Josephat M. Chinawa ${ }^{1 *}$, Bartholomew F. Chukwu², Awoere T. Chinawa ${ }^{3}$ and Chika O. Duru ${ }^{4}$
}

\begin{abstract}
Introduction: Patent ductus arteriosus (PDA) is a common acyanotic heart disease that presents with variable symptoms.

Objectives: This study is therefore aimed at determining the relationship between gender, age, and size of PDA and pulmonary hypertension. This study also seeks to determine the prevalence of elevated pulmonary artery systolic pressure in children with PDA.

Patients and methods: A descriptive study of children with patent ductus arteriosus was carried out from 2016 to 2020 in three institutions. The data were analysed with the IBM SPSS statistics for windows, version 20 (IBM Corp, Chicago)

Result: The mean ductal size was $3.78(2.39) \mathrm{mm}$, with a minimum of $1.0 \mathrm{~mm}$ and a maximum size of $10.0 \mathrm{~mm}$. The mean ductal size for males, 4.02 (2.53) $\mathrm{mm}$ was comparable with that of the females, 3.61 (2.28) $\mathrm{mm}$ (Student T-test $=0.8,0.4)$. The mean pulmonary artery systolic pressure (PASP) of the patients was $43.36(24.46) \mathrm{mmHg}$. Also the mean PASP was comparable among the males and the females, 48.37 (26.69) $\mathrm{mmHg}$ versus $39.63(22.16) \mathrm{mmHg}$ (Student T-test $=1.81, p=0.07$ ). There was no correlation between age and PASP (correlation coefficient $=0.009$, $p=0.92)$. Sixty point two percent (60.2\%) $(62 / 103)$ of children with PDA had pulmonary hypertension. The proportion of males with pulmonary hypertension, 48.39\% (30/62) was comparable with that of the females, 51.61\% (32/62) $\left(\mathrm{Chi}^{2}=2.05, \mathrm{p}=0.15\right)$ and females are 1.8 times more likely to have pulmonary hypertension as males (odds ratio 1.81, $95 \% \mathrm{Cl}$ 0.8-4.1). There was a positive correlation between ductal size and PASP (Pearson correlation coefficient $=0.26$, $p$ value $=0.007$ ). Those with moderate and large sized duct tend to have moderate and severe pulmonary hypertension respectively and this is statistically significant. $\mathrm{Chi}^{2}=17.85, \mathrm{p}=0.007$

Conclusion: The prevalence of pulmonary hypertension in children with PDA is $60.2 \%$. Moderate and large size duct presents with moderate and severe pulmonary hypertension respectively. Females are 1.8 times more likely to have pulmonary hypertension than the males.
\end{abstract}

Keywords: PDA, Ductal size, Pulmonary hypertension, Children

*Correspondence: josephat.chinawa@unn.edu.ng

${ }^{1}$ Pediatric Cardiologist, College of Medicine, Department of Pediatrics, University of Nigeria/University of Nigeria Teaching Hospital (UNTH), Ituku-Ozalla, Enugu State, Nigeria

Full list of author information is available at the end of the article

\section{Introduction}

The ductus arteriosus is a remnant of the distal sixth aortic arch. Patent ductus arteriosus (PDA) is usually a left aortic remnant [1]. It could be right-sided or even

(c) The Author(s) 2021. Open Access This article is licensed under a Creative Commons Attribution 4.0 International License, which permits use, sharing, adaptation, distribution and reproduction in any medium or format, as long as you give appropriate credit to the original author(s) and the source, provide a link to the Creative Commons licence, and indicate if changes were made. The images or other third party material in this article are included in the article's Creative Commons licence, unless indicated otherwise in a credit line to the material. If material is not included in the article's Creative Commons licence and your intended use is not permitted by statutory regulation or exceeds the permitted use, you will need to obtain permission directly from the copyright holder. To view a copy of this licence, visit http://creativecommons.org/licenses/by/4.0/. The Creative Commons Public Domain Dedication waiver (http://creativeco mmons.org/publicdomain/zero/1.0/) applies to the data made available in this article, unless otherwise stated in a credit line to the data. 
bilateral.

The prevalence of PDA is variable ranging from [5 to $10 \%][1,2]$. This lesion is the major cause of mortality and morbidity in infancy. If not closed, it could lead to pulmonary hypertension later in life [3]. The hemodynamic effects of PDA are well known including pulmonary hypertension, systemic hypo-perfusion, and volume overload on the left ventricle [4].

In children with isolated PDA, shunt volume and pulmonary hypertension are determined by the size of the open communication and the pulmonary vascular resistance (PVR) [5]. Pulmonary overflow results in decreased pulmonary compliance and the magnitude of the excess pulmonary blood flow depends on some factors [1]. The larger the internal diameter of the mostnarrow portion of the ductus arteriosus, the larger the left-to-right shunt, and thus the higher the chance of pulmonary hypertension. If the ductus arteriosus is small or narrow, the magnitude of the shunt will also be affected [1,6]. Furthermore, the magnitude of the leftto-right shunt is partially controlled by the relationship of PVR to the systemic vascular resistance (SVR). If the SVR is high and/or the PVR is low, the flow through the ductus arteriosus is potentially large [6].

Age is an important predictor of pulmonary hypertension and pulmonary vascular disease (PVD). It has been postulated that PDA may have a more marked effect on the pulmonary circulation than a ventricular septal defect and that irreversible pulmonary vascular changes may occur under two years of age [7]. This could be explained by the high-pressure pulsatile flow transmitted from the aorta to the pulmonary artery throughout the cardiac cycle in PDA.

It is very pertinent to note that echocardiographic assessment of right ventricular function and measurements of peak velocities of valvar regurgitations are the two major approaches that predict pulmonary artery systolic pressure measurements of PDA [8, 9]. Granted that the right-sided heart catheterization is very crucial in assessing pulmonary artery pressure in children especially for operability, however, it is obvious that performing catheterization in all patients with heart disease will be expensive, impractical, and with its attendant risk factors [8-11]. Echocardiographic assessment of pulmonary artery pressure in children with PDA is therefore very simple, accurate, and safe with a very high cost-benefit ratio [8-10].

Assessment of pulmonary artery systolic pressure in children with PDA is very crucial in this setting, as it will help in risk categorization and timely initiation of management. A careful search in the literature showed that there is no single study in Nigeria on this topic.
No known study in this vicinity looked at any link between the size of PDA and pulmonary hypertension. This study is therefore aimed at determining the relationship between gender, age, and size of PDA and pulmonary hypertension. This study also seeks to determine the prevalence of elevated pulmonary artery systolic pressure in children with PDA.

\section{Materials and methods}

\section{Study area}

This is an observational cross-sectional study, carried out in one private and two public hospitals namely the University of Nigeria Teaching Hospital, Blessed children hospital and Niger Delta University, over a-six-year period from 2016 to 2020.

\section{Study population}

These were children aged one month to 14 years who attended the paediatric cardiology clinics of the three hospitals of study.

\section{Study design}

This was an observational cross-sectional study conducted in three institutions from the year 2016 to 2020.

\section{Inclusion and exclusion criteria}

Children with PDA aged one month to 14 years and who gave consent or assent were included in the study while children whose parents did not give verbal consent and children with previously corrected congenital heart disease were excluded from the study. Preterm infants and infants less than 1-month old were also excluded from the study.

\section{Consent}

Verbal consent for echocardiography was obtained from each parent/caregiver of the subjects from the time they presented to the clinic for cardiac evaluation.

\section{Child assent}

This was obtained in children who were older than seven years.

The study had a quality control where other cardiologist made a diagnosis of congenital heart disease at different intervals to reduce bias.

\section{Definition of Patent ductus arteriosus using echocardiography}

The best view for measuring the size of the PDA is the ductal view. This is otherwise called the high left parasternal short-axis view. Paying attention to the main pulmonary artery, the origin of the right pulmonary artery and the left pulmonary artery can be seen, the PDA could 
be visualized at the left. The size of the PDA was taken at the narrowest point, before it entered into the main pulmonary artery [12].

\section{Assessment of size of patent ductus arteriosus}

In this research work, insignificant or small size PDA was taken as the diameter of patent ductus arteriosus of 1-1.5 mm, moderate size PDA was taken as the diameter of patent ductus arteriosus of 1.5-3 mm while large size PDA is taken as the diameter of patent ductus arteriosus of more than and equal to $3 \mathrm{~mm}$ [13].

\section{Assessment of pulmonary hypertension}

At the 6th World Symposium on Pulmonary Hypertension $(\mathrm{PH})$, the mean pulmonary artery systolic pressure(mPAP) the threshold for pulmonary hypertension which was formerly $\geq 25 \mathrm{mmHg}$ has been changed to mean pulmonary artery systolic pressure $(\mathrm{mPAP})>20 \mathrm{mmHg}$ [14]. The rationale for this change is that the threshold $\geq 25 \mathrm{mmHg}$ is determined by individual preference or convenience, whereas the new threshold is based on scientific evidence. This change may facilitate earlier $\mathrm{PH}$ detection, risk stratification and screening programmes [14].

Pulmonary hypertension was calculated in this study by summing the calculated pressure gradient over the tricuspid valve and right atrial pressure.

Normal right atrial pressure of $3 \mathrm{mmHg}$ is usually added to TR velocity when the IVC is normal in size and collapsible, high right atrial pressure of $15 \mathrm{mmHg}$ is added to TR Velocity when the IVC is dilated and does not collapse normally. However, intermediate values of $8 \mathrm{mmHg}$ will be added to TR velocity in any scenario that does not meet the normal and high values. We used the third criteria where RA pressure of $8 \mathrm{mmHg}$ was added to TR velocity to get pulmonary artery systolic pressure. According to current guidelines by Chemla et al. [15], pulmonary hypertension is defined if mean pulmonary artery pressure is above $20 \mathrm{mmHg}$. Mean pulmonary artery pressure of $20 \mathrm{mmHg}$ corresponds to pulmonary artery systolic pressure of about $30 \mathrm{mmHg}$. So in this study, pulmonary artery systolic pressure of $30 \mathrm{mmHg}$ was taken as pulmonary hypertension [15]. Pulmonary hypertension was classified as mild $=30-50 \mathrm{mmhg}$; moderate $=51-65 \mathrm{mmhg}$ and severe $\geq 65 \mathrm{mmHg}$ [16].

Children who had PDA were examined in a supine, left lateral decubitus position. The views of PDA were obtained in subcostal, left parasternal, apical, and suprasternal windows [17].

We used the Bernoulli equation to estimate the pulmonary arterial systolic pressure $(\mathrm{PASP}=4 \mathrm{~V} 2+$ right atrial pressure) where $\mathrm{V}$ indicates peak systolic velocity of the regurgitant jet as far as pulmonary stenosis is ruled out $[13,14]$.

\section{Statistical analysis}

The data were analysed with the IBM SPSS statistics for windows, version 20 (IBM Corp, Chicago). Categorical variables were analysed in form of proportions and percentages and presented in form of tables. Continuous variables including ductal size and pulmonary artery pressure were analysed and summarized as means and standard deviations. Means of continuous variables were compared with the Student T- test while categorical variables were compared with Chi-square. Correlation between continuous variables was determined using Pearson correlation. Gender probability of having pulmonary hypertension was reported using adjusted odds ratios (AOR) and 95\% confidence interval. Test of significance was set at $\mathrm{p}<0.05$.

\section{Result}

\section{Demography}

One hundred and four (104) patients aged one month to 14 years were evaluated for the effect of ductal size on the severity of pulmonary artery systolic pressure (PASP) among children with patent ductus arteriosus (PDA). The males comprised $42.3 \%(44 / 104)$. The mean age of the patients was 22.72 (35.46) months. Pulmonary hypertension was more in infants than older children, $54.5 \%$ versus $45.5 \%$, although the difference was not statistically significant $\left(x^{2}=0.3, p=0.6\right)$, (odd ratio $=0.8,95 \%$ confidence interval; 0.3-1.9).

\section{Ductal size and pulmonary artery systolic pressure}

The mean ductal size was $3.78(2.39) \mathrm{mm}$, with a minimum of $1.0 \mathrm{~mm}$ and a maximum size of $10.0 \mathrm{~mm}$. The mean ductal size for males, 4.02 (2.53) $\mathrm{mm}$ was comparable with that of the females, $3.61(2.28) \mathrm{mm}$ (Student T-test $=0.8,0.4)$. We classified ductal size into small, moderate and large and Table 1 illustrates the frequency of occurrence of the different sizes.

The mean PASP of the patients was 43.36 (24.46) $\mathrm{mmHg}$. Also the mean PASP was comparable among the

Table 1 Frequency of different classes of ductal size

\begin{tabular}{llc}
\hline Class of ductal size & Frequency & Percent \\
\hline Small & 22 & 21.4 \\
Moderate & 31 & 30.1 \\
Large & 50 & 48.5 \\
Total & $103^{\mathrm{a}}$ & 100.0 \\
\hline
\end{tabular}

${ }^{a}$ One patient did not have data for ductal size 
males and the females, 48.37 (26.69) $\mathrm{mmHg}$ versus 39.63 (22.16) $\mathrm{mmHg}$ (Student T-test $=1.81, \mathrm{p}=0.07$ ). There was no correlation between age and PASP (correlation coefficient $=0.009, \mathrm{p}=0.92$ ).

\section{Pulmonary hypertension}

PASP of $30 \mathrm{mmHg}$ and above was regarded as pulmonary hypertension and it was observed that $60.2 \%$ (62/103) had pulmonary hypertension. The proportion of males with pulmonary hypertension, $48.39 \%(30 / 62)$ was comparable with that of the females, $51.61 \%(32 / 62)$ $\left(x^{2}=2.05, p=0.15\right)$, although the females are 1.8 times more likely to have pulmonary hypertension as the males (odds ratio 1.81, 95\% CI 0.8-4.1).

The severity of pulmonary hypertension was also classified into mild, moderate and severe and the frequency of different severities shown in Table 2.

The relationship between ductal size and severity of pulmonary hypertension is shown in Table 3 which revealed that $42.86 \%$ of those with small ductal size had mild pulmonary hypertension and none had severe pulmonary hypertension while $44.44 \%$ of those with large ductal size had mild hypertension and $33.33 \%$ had severe pulmonary hypertension. Those with moderate and large-sized duct tend to have moderate and severe pulmonary hypertension respectively and this is statistically significant. $X^{2}=17.85, \mathrm{p}=0.007$.

\section{Correlation between size of PDA and PASP}

There was a positive correlation between ductal size and PASP as illustrated in Fig. 1 (Pearson correlation

Table 2 Frequency of different severities of pulmonary hypertension

\begin{tabular}{llc}
\hline Severity & Frequency & Percent \\
\hline Mild & 22 & 35.48 \\
Moderate & 19 & 30.65 \\
Severe & 21 & 33.87 \\
Total & 62 & 100.0 \\
\hline
\end{tabular}

coefficient $=0.26, \mathrm{p}$ value $=0.007$ ). As the ductal size increases, the PASP also increases. There was no correlation between age of patients and size of PDA as shown in Fig. 2, (correlation coefficient $=-0.10, p=0.32$ ).

\section{Prevalence of PDA}

Seven hundred and fifty-eight (758) echocardiography reports on children with cardiac disease were studied and a diagnosis of PDA was in 104 children giving a prevalence of $13.9 \%$.

\section{Discussion}

Pulmonary artery systolic pressure is an integer and harbinger of pulmonary hypertension [1]. Pulmonary artery systolic pressure is a mirror image of right heart haemodynamic, and is very important in the diagnosis of pulmonary hypertension. Pulmonary hypertension has been noted as the fourth most prevalent cardiovascular disease in the world, though this goes unnoticed by the WHO Global Action Plan and Global Burden of Diseases [2]. Data on the world prevalence of pulmonary hypertension in children with PDA is lacking; a well-knitted and coordinated action is therefore needed for screening and intervention [3].

The prevalence of pulmonary hypertension in children with PDA in this study is $60.2 \%$ and is more with a large ductal size. Progressive hypertension, intimal proliferation and prolonged hypoxaemia could explain this phenomenon [18-20]. Weijerman et al. [21] noted a prevalence of $5.8 \%$ but this was mainly among termed neonates. Our study transcends neonatal age. Studies on the prevalence of pulmonary hypertension were mainly among children with congenital heart disease and there is a paucity of studies in children with PDA. The available prevalence of pulmonary hypertension was focused on preterm babies.

It is evidenced from this study, that children with moderate and large-sized duct tend to have moderate and severe pulmonary hypertension respectively. Studies have shown that increase blood volume that shunts to the right heart towards the lung from a large patent PDA and

Table 3 Relationship between the class of ductal size and severity of pulmonary hypertension

\begin{tabular}{|c|c|c|c|c|}
\hline \multirow[t]{2}{*}{ Class of ductal size } & \multirow{2}{*}{$\begin{array}{l}\text { Severity of pulmonary } \\
\text { hypertension }\end{array}$} & \multicolumn{3}{|l|}{ Total n (\%) } \\
\hline & & Mild n(\%) & Moderate n(\%) & Severe $n^{3}(\%)$ \\
\hline Small & $3(42.86)$ & $4(57.14)$ & $0(0)$ & $7(100)$ \\
\hline Moderate & $3(15.79)$ & $7(36.84)$ & $9(47.37)$ & $19(100)$ \\
\hline Large & $16(44.44)$ & $8(22.22)$ & $12(33.33)$ & $36(100)$ \\
\hline Total & $22(35.48)$ & 19 (30.65) & 21 (33.87) & $62(100)$ \\
\hline
\end{tabular}

Chi-square $=17.85, p=0.007$ 


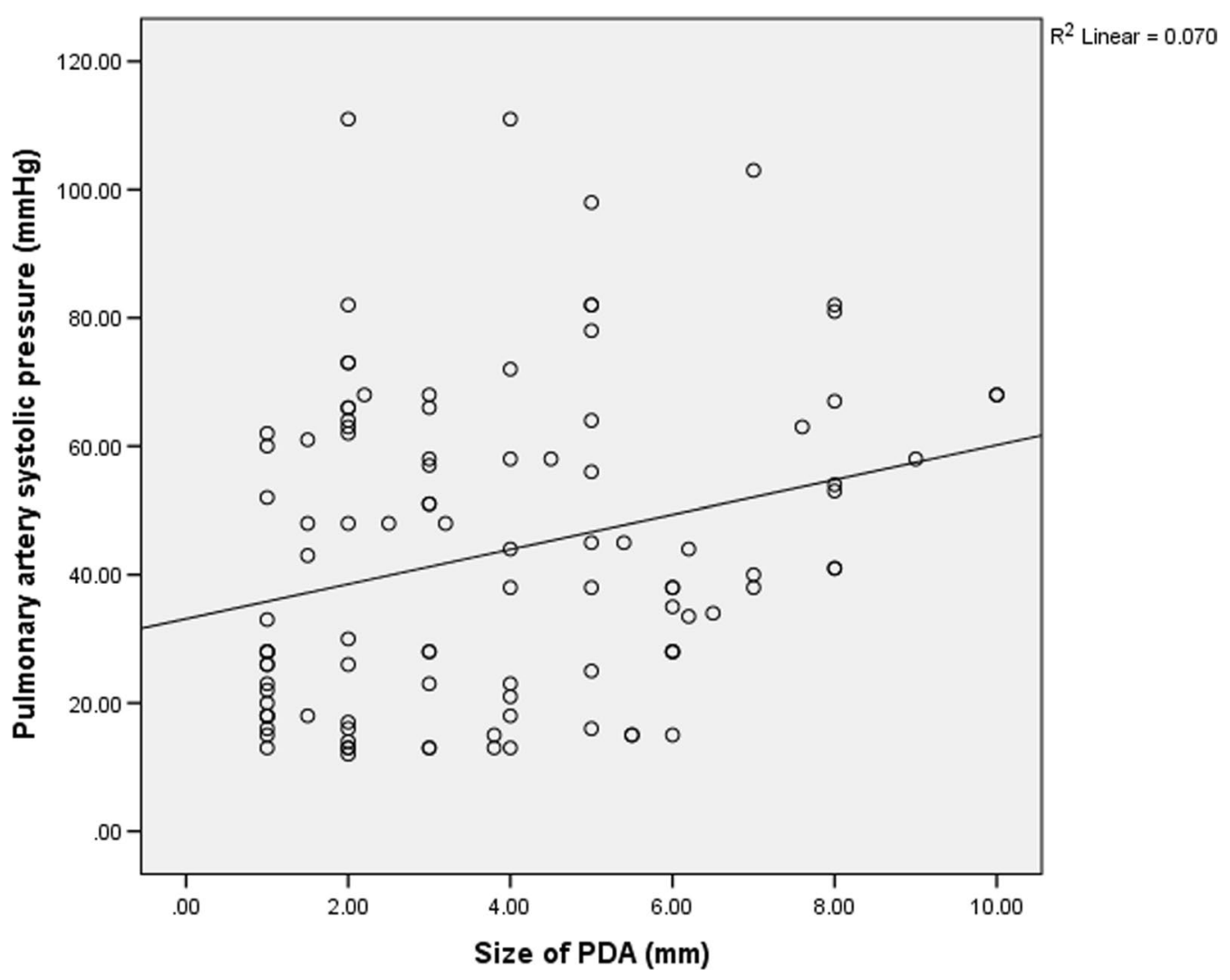

Fig. 1 Correlation between pulmonary artery systolic pressure and size of PDA

laxity of the vasa-vasorum in the duct could all account for this high risk of pulmonary hypertension among children with large sized PDA [12]. Niu et al. [22], also noted that large PDA could result in severe pulmonary hypertension and irreversible pulmonary vascular disease. They realized that when this large PDA was closed with a catheter, that right ventricular failure usually ensues. In a large ductus arteriosus, there is build up in pulmonary artery pressure with resultant turbulent flow across the defect. With this continued shunt, coupled with neovascularization and intimal proliferation, there could be a shunt reversal and pulmonary vascular disease [23].

Though age at presentation has been noted not to correlate with pulmonary hypertension, however, infants have more odds and are seen to present with pulmonary hypertension than older children. This is quite contrary to other studies where children less than 1 year of age are unlikely to present with features of pulmonary arterial hypertension [7, 24-27].

The increased episodes of pulmonary hypertension among older children as seen in other studies, could be due to the fact that high-pressure and pulsatile flow from the aorta to the pulmonary artery, if not arrested by closure or ligation, could lead to progression of vascular disease (PVD), with increased pulmonary artery pressure more than systemic pressure, there could be a shunt reversal, leading to eisenmenger syndrome [7, 26-29]. There is general agreement that patients with eisenmenger syndrome should not have the defect closed and in fact, the defect can be beneficial because the defect acts as an outlet for the right ventricle (RV) to pump into the systemic circulation and maintain cardiac output at the cost of arterial desaturation [23-25, 30,31].

This study reveals that female children with PDA are 1.8 times more likely to have pulmonary hypertension than the male counterparts. This finding is documented by other researchers who also noted a female preponderance in children with elevated pulmonary pressures [3234]. The theory of "sex paradox" elaborated in pulmonary hypertension has long been known in females. They have a higher susceptibility than males with a female-to-male ratio is 4:1 [33]. Genetic factors have been linked to this increased risk in female children. A genetic mutation in the bone morphogenetic protein 2 (BMPR2) gene has been linked to pulmonary arterial hypertension. Females children are more likely to express the mutation in the BMPR2 receptor [33]. 


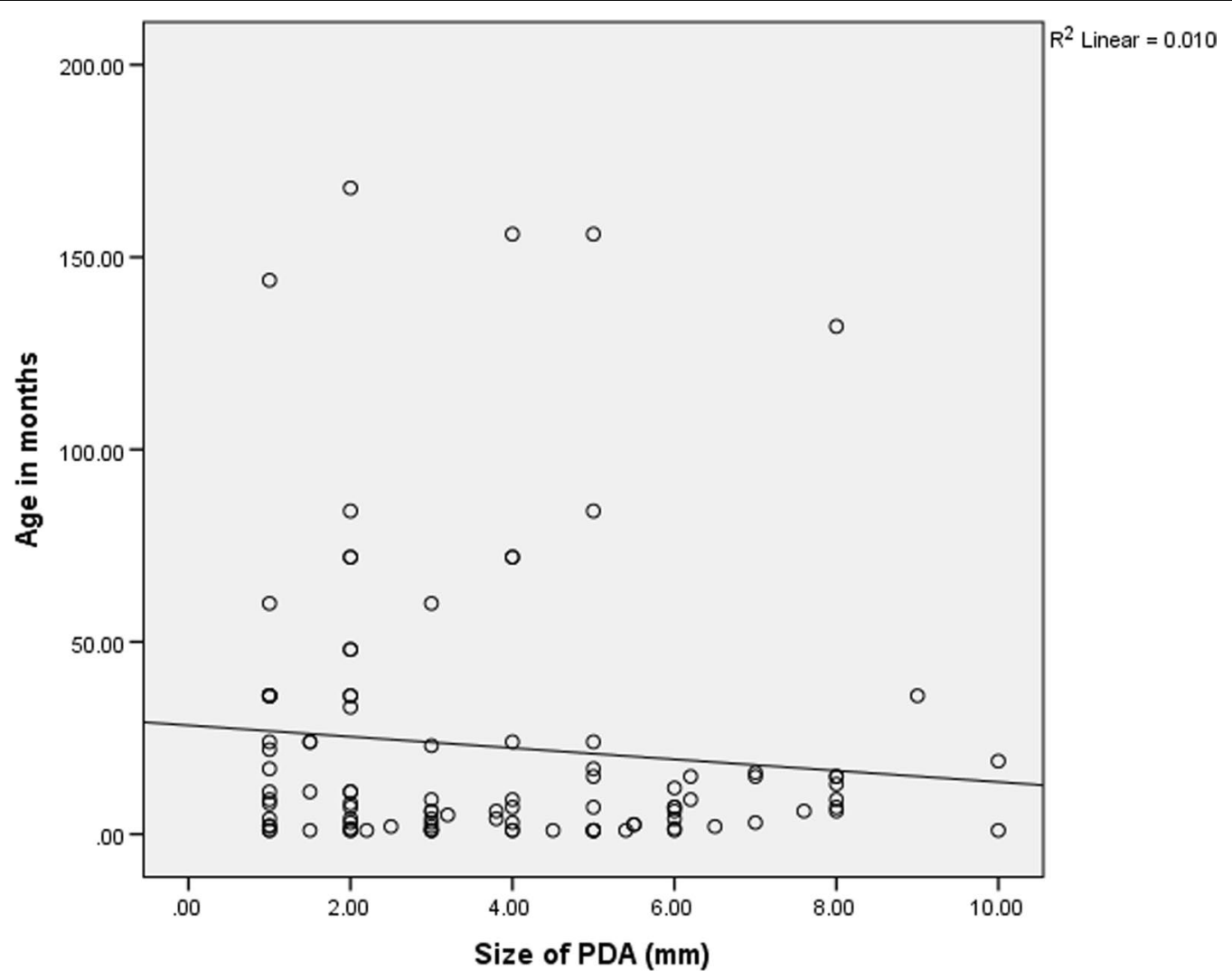

Fig. 2 Correlation between age of patients and size of PDA

Several studies have investigated the link between BMPR2 and oestrogen signalling, which has been proposed as a very important trigger for female predominance. For instance, Austin et al. [37] noted that when oestrogen receptor alpha binds to the BMPR2 promoter, its gene expression was remarkably reduced in females [33]. Similarly, recent studies have noted that sex chromosomes as another reason for females to have a higher likelihood for pulmonary hypertension. Yan et al. [35] demonstrated that SRY on the Y chromosome regulates and binds to the BMPR2 receptor and promoter to reduce the prevalence of PAH in males [33].

The World Health Organization (WHO) Group 1 for pulmonary hypertension and other studies noted that the female predominance could be related to differences in their immune system [34-37].

The prevalence of Patent ductus arteriosus noted in this study is $13.9 \%$. This prevalence rate is different from that obtained in the US which showed an estimated prevalence of between $0.02 \%$ and $0.006 \%$ of babies born at term [38]. However, the reported prevalence of PDA in term neonates is 1 in 2,000 births, accounting for $5 \%-10 \%$ of all congenital heart disease [6].

\section{Conclusion}

The prevalence of pulmonary hypertension in children with PDA is $60.2 \%$. Moderate and large size duct presents with moderate and severe pulmonary hypertension respectively. Females are 1.8 times more likely to have pulmonary hypertension than the males.

\section{Recommendations}

Early closure or ligation PDA is recommended to avert the development of pulmonary hypertension in children especially those with large PDA (Additional file 1).

\section{Strength of the study}

This is the first time this work is done in the vicinity and can form a template for other studies. In addition, its multi -enter nature gives it an added advantage.

\section{Limitations}

Sample size is relatively not large. 


\section{Supplementary Information}

The online version contains supplementary material available at https://doi. org/10.1186/s12890-021-01449-y.

Additional file 1. Additional file containg the raw data of SPSS.

\section{Acknowledgements}

We acknowledge those that work in echo room for retrieving all necessary documents

\section{Authors' contributions}

JMC conceived and designed this study while JMC, BFC, ATC and COD helped in critical revision of the article. JMC and BFC also did the Data analysis/interpretation. All authors have read and approved the manuscript.

\section{Funding}

This study was not funded by any organization. We bore all the expense that accrued from in study.

\section{Availability of data and materials}

All data generated or analysed during this study are included in this article [and its supplementary information files].

\section{Declarations}

\section{Ethics approval and consent to participate}

This complies with national guidelines [22]. All procedures performed in studies involving human participants were in accordance with the ethical standards of the institutional and/or national research committee and with the 1964 Helsinki declaration and its later amendments or comparable ethical standard. Ethical approval was obtained from the Ethics and Research committee of the University of Nigeria Teaching hospital Enugu (IRB number of 00002323). Informed written consent was also granted by the parents/caregivers of subjects, before they were recruited.

\section{Consent for publication}

Not applicable.

\section{Competing interests}

The authors declare that they have no competing interests.

\section{Author details}

${ }_{1}$ Pediatric Cardiologist, College of Medicine, Department of Pediatrics, University of Nigeria/University of Nigeria Teaching Hospital (UNTH), Ituku-Ozalla, Enugu State, Nigeria. ${ }^{2}$ Department of Pediatrics, University of Nigeria/University of Nigeria Teaching Hospital (UNTH), Enugu State, Ituku-Ozalla, Nigeria.

${ }^{3}$ Enugu State University Teaching Hospital, Enugu, Enugu State, Nigeria.

${ }^{4}$ Department of Paediatrics and Child Health, Niger Delta University Teaching Hospital, Okolobiri, Bayelsa State, Nigeria.

Received: 24 October 2020 Accepted: 10 February 2021

Published online: 05 March 2021

\section{References}

1. Kaemmerer H, Meisner H, Hess J, Perloff JK. Surgical treatment of patent ductus arteriosus: a new historical perspective. Am J Cardiol. 2004:94:1153-4.

2. Chaudhury M, Sohel MA, Muhammad KH, Abed HK, Lima AS, Ashraf US. Validity of estimation of pulmonary artery pressure using continuous wave Doppler echocardiography in patient with patent ductus arteriosus (PDA). Univ Heart J. 2011:7:10-2.

3. Arlettaz R. Echocardiographic evaluation of patent ductus arteriosus in preterm infants. Front Pediatr. 2017:5:147.

4. Philip R, Nathaniel Johnson J, Naik R, Kimura D, Boston U, Chilakala S, et al. Effect of patent ductus arteriosus on pulmonary vascular disease. Congenit Heart Dis. 2019;14:37-41.
5. Condo M, Evans N, Bellu R, Kluckow M. Echocardiographic assessment of ductal significance: retrospective comparison of two methods. Arch Dis Child Fetal Neonatal Ed. 2012;97:35-8.

6. Schneider DJ, Moore JW. Patent ductus arteriosus. Circulation. 2006:114:1873-82

7. Tharakan J, Venkateshwaran S. Large patent ductus arteriosus: to close or not to close. Ann Pediatr Cardiol. 2012;5:141-4.

8. Global, regional, and national burden of congenital heart disease, 1990-2017: a systematic analysis for the Global Burden of Disease Study. 2020; 4:185-200

9. van Laere D, van Overmeire B, Gupta S, El-Khuffash A, Savoia M, McNamara PJ, Schwarz CE, de Boode WP. European Special Interest Group 'Neonatologist Performed Echocardiography' (NPE). Application of NPE in the assessment of a patent ductus arteriosus. Pediatr Res. 2018:84:46-56.

10. Why does congenital heart disease cause failure to thrive? Obtainable from https://adc.bmj.com/content/archdischild/60/12/1134.full.pdf. Assessed on 02/06/2020.

11. Vaidyanathan B, Nair SB, Sundaram KR, Babu UK, Shivaprakasha K, Rao SG, et al. Malnutrition in children with congenital heart disease (CHD) determinants and short term impact of corrective intervention. Indian Pediatr. 2008;45:541-6.

12. Chugh R, Salem MM. Echocardiography for patent ductus arteriosus including closure in adults. Echocardiography. 2015;32:125-39.

13. McNamara PJ, Sehgal A. Towards rational management of the patent ductus arteriosus: the need for disease staging. Arch Dis Child Fetal Neonatal Ed. 2007;92:424-7.

14. Simonneau G, Hoeper MM. The revised definition of pulmonary hypertension: exploring the impact on patient management. Eur Heart J Suppl. 2019;21:4-8.

15. Chemla D, Humbert M, Sitbon O, Montani D, Hervé P. Systolic and mean pulmonary artery pressures: are they interchangeable in patients with pulmonary hypertension? Chest. 2015;147(4):943-50. https://doi.org/10. 1378/chest.14-1755.

16. Pulmonary Hypertension Echocardiography LITFL CCC. Obtainable from https://litfl.com/pulmonary-hypertension-echocardiography/. Accessed on $13 / 01 / 2021$

17. Kang C, Zhao E, Zhou Y, et al. Dynamic changes of pulmonary artery systolic pressureand ductus arteriosus in human new-borns from birth to 72 hours of age. Medicine (Baltimore). 2016;95:2599.

18. How to assess pulmonary hypertension|123sonography Obtainable from https://www.123sonography.com/ebook/assess-pulmonary-hypertensi on. Assessed on 22/10/2020.

19. Fortescue EB, Lock JE, Galvin T, McElhinney DB. To close or not to close: the very small patent ductus arteriosus. Congenit Heart Dis. 2010;5(4):354-65

20. Tripathi A, Black GB, Park YM, Jerrell JM. Prevalence and management of patent ductus arteriosus in a paediatric medical cohort. Clin Cardiol. 2013;36:502-6.

21. Weijerman $M E$, van Furth $A M$, van der Mooren MD, van Weissenbruch MM, Rammeloo L, Broers CJ, Gemke RJ. Prevalence of congenital heart defects and persistent pulmonary hypertension of the neonate with Down syndrome. Eur J Pediatr. 2010;169:1195-9.

22. Niu MC, Mallory GB, Justino H, Ruiz FE, Petit CJ. Treatment of severe pulmonary hypertension in the setting of the large patent ductus arteriosus. Pediatrics. 2013;131:1643-9.

23. Berra G, Noble S, Soccal PM, Beghetti M, Lador F. Pulmonary hypertension in the elderly: a different disease? Breathe (Sheff). 2016;12:43-9.

24. Peacock AJ, Murphy NF, McMurray JJ, Caballero L, Stewart S. An epidemiological study of pulmonary arterial hypertension. Eur Respir J. 2007:30:104-9.

25. Ranjit P, Jason NJ, Ronak N, Dai K, Umar B, Sandeep C, Benjamin H, et al. Effect of patent ductus arteriosus on pulmonary vascular disease. Congenit Heart Dis. 2019;14:37-41.

26. Sook KY, Cheong JM, Young AY, Jae YL, In KS. Echocardiographic assessment of patent ductus arteriosus in very low birthweight infants over time: prospective observational study. J Maternal Fetal Neonatal Med. 2018;2:164-72

27. Sun M, Cheng C, Zhang R, et al. Zhonghua Xin Xue Guan Bing Za Zhi. Pulmonary hypertension after operation for congenital heart disease: Analysis of risk factors and management. J Thorac Cardiovasc Surg. 2014:42:396-9. 
28. Blount SG, Vogel JH. Pulmonary hypertension. In: Moss AJ, Adams FH, editors. Heart Disease in Infants, Children and Adolescents. Baltimore: Williams and Wilkins. Obtainable from https://shop.lww.com/MossAdams-Heart-Disease-in-Infants-Children-and-Adolesce. Assessed on $17 / 06 / 2020$

29. Docherty CK, Harvey KY, Mair KM, Griffin S, Denver N, MacLean MR. The role of sex in the pathophysiology of pulmonary hypertension. Adv Exp Med Biol. 2018;1065:511-28.

30. Shahnaz P, Nazanin F, Deepak S, Sirous C, Farhad B. Prevalence and risk factors associated with the patency of ductus arteriosus in premature neonates: a prospective observational study from Iran. J Matern Fetal Neonatal Med. 2017;30(12):1460-4.

31. Hagau N, Culcitchi C. Nutritional support in children with congenital heart disease. Nutr Ther Metab. 2010;28:172-84.

32. Barbro K, Magnus N, David K, Sven-Erik B, Bodil I, Göran R, et al. Sexspecific differences and survival in patients with idiopathic pulmonary arterial hypertension 2008-2016. ERJ Open Res. 2019;5:00075-2019. https://doi.org/10.1183/23120541.00075-2019.

33. Evans JD, Girerd B, Montani D, Wang XJ, Galiè N, Austin ED, Elliott G, Asano K, Grünig E, et al. BMPR2 mutations and survival in pulmonary arterial hypertension: an individual participant data meta-analysis. Lancet Respir Med. 2016:4:129-37.
34. Austin ED, Hamid R, Hemnes AR, Loyd JE, Blackwell T, Yu C, Phillips lii JA, Gaddipati R, Gladson S, Gu E, West J, Lane KB. BMPR2 expression is suppressed by signaling through the estrogen receptor. Biol Sex Differ. 2012;3:6.

35. Yan L, Cogan JD, Hedges LK, Nunley B, Hamid R, Austin ED. The Y chromosome regulates BMPR2 expression via SRY: a possible reason "why" fewer males develop pulmonary arterial hypertension. Am J Respir Crit Care Med. 2018;198:1581-3.

36. Foderaro A, Ventetuolo CE. Pulmonary arterial hypertension and the sex hormone paradox. Curr Hypertens Rep. 2016;18:84.

37. Wiyono SA, Witsenburg M, de Jaegere PP, Roos-Hesselink JW. Patent ductus arteriosus in adults: Case report and review illustrating the spectrum of the disease. Neth Heart J. 2008;16(7-8):255-9. https://doi.org/10.1007/ BF03086157.

38. What is the prevalence of patent ductus arteriosus (PDA)? Obtainable from. https://www.medscape.com/answers/891096-69142/what-is-theprevalence-of-patent-ductus-arteriosus-pda. Accessed on 18/01/2021.

\section{Publisher's Note}

Springer Nature remains neutral with regard to jurisdictional claims in published maps and institutional affiliations.
Ready to submit your research? Choose BMC and benefit from:

- fast, convenient online submission

- thorough peer review by experienced researchers in your field

- rapid publication on acceptance

- support for research data, including large and complex data types

- gold Open Access which fosters wider collaboration and increased citations

- maximum visibility for your research: over $100 \mathrm{M}$ website views per year

At BMC, research is always in progress.

Learn more biomedcentral.com/submissions 